\title{
Contrasting presentation of solitary scapular osteochondroma: a report of three cases and review of literature
}

\author{
Ajay Alex Varughese, Ritesh Arvind Pandey*, Rajesh Paul, Bobby John
}

Department of Orthopaedics, Christian Medical College and Hospital, Ludhiana, Punjab, India

Received: 19 January 2020

Revised: 24 September 2020

Accepted: 29 September 2020

\author{
*Correspondence: \\ Dr. Ritesh Pandey, \\ E-mail: riteshpandey8262@yahoo.com
}

Copyright: (c) the author(s), publisher and licensee Medip Academy. This is an open-access article distributed under the terms of the Creative Commons Attribution Non-Commercial License, which permits unrestricted non-commercial use, distribution, and reproduction in any medium, provided the original work is properly cited.

\begin{abstract}
Scapular osteochondroma can have unusual manifestations like pseudo-winging and snapping syndrome in ventrally located lesions. Dorsally located lesions cause a cosmetic blemish and difficulty in lying supine. We present a series of 3 cases of scapular osteochondroma with varying presentations. One was a ventral surface (subscapular) osteochondroma which presented with pseudo winging and snapping syndrome and 2 were dorsal surface osteochondromas which presented with prominence at the back and difficulty in lying supine. All were treated surgically with good functional and cosmetic results. Surgical resection of tumor is the treatment of choice. An appropriate surgical approach should be chosen depending on the location of tumor. We propose the use of trapezius sparing approach and splitting the scapular apophysis for subscapular osteochondroma in children as it produces less soft tissue damage, is easy to repair and allows early rehabilitation.
\end{abstract}

Keywords: Scapular osteochondroma, Pseudo-winging, Subscapular, Exostosis, Trapezius sparing

\section{INTRODUCTION}

Osteochondroma is a benign cartilaginous tumour accounting for $3 \%$ of all tumours in general population. ${ }^{1}$ It is commonly found in young patients, generally aged below 30 years, with a male: female ratio of $1.5: 1$. It is considered the most common benign tumour originating from bone, accounting for $15 \%$ of all bone tumours \& 45 $47 \%$ of benign bone tumours. ${ }^{2-6}$

They are common in juxta-articular positions of long bones like distal femur, proximal tibia and proximal humerus. Scapular osteochondroma though rare is a known entity. In scapula, they can have unusual manifestations in terms of site, age of onset and atypical presenting signs and symptoms. Diagnosis may be sometimes challenging due to unawareness about these atypical presentations. Ventral scapular ostoechondromas are known to cause pseudo-winging and is often misdiagnosed as winging of scapula due to serratus anterior muscle palsy. Due to its ventral location, the mass is often not palpable. Furthermore, it may not be evident on routine antero-posterior radiographs. Similarly, it may produce snapping syndrome and can be confused with bursitis and chest wall pathology. ${ }^{4-14}$ Dorsal scapular osteochondroma presents as a visible mass and should be differentiated with other pathologies with similar presentation. They tend to cause a cosmetic blemish and difficulty in lying supine. ${ }^{15}$ Here we present a case series of 3 patients with scapular osteochondroma with different presentation in different location with details of surgical steps and review of literature.

\section{CASE REPORT}

\section{Case 1}

A seven-year-old girl presented to our Orthopaedic department with progressive deformity of left shoulder for one year (Figure 1). Patient had no pain or limitation of 
movements of the shoulder. Abduction of left shoulder produced a grating sensation (snapping). On examination a pseudo-winging also known as static winging of scapula was noted, the winging was not more prominent against resistance and muscle strength of serratus anterior and neurological examination was normal. A CT evaluation of the thorax and shoulder showed a well-defined, pedunculated bony lesion arising from the ventral aspect of infero-medial angle of left scapula which was pushing against the rib cage. The imaging features were consistent with that of a scapular osteochondroma. She underwent an excision biopsy of the lesion: patient was positioned prone, tumour was approached by an incision over medial border of scapula. Subcutaneous tissue was sharply dissected to reach scapular apophysis which was then split longitudinally with a scalpel. The sub-periosteal plane of inner table of scapula was then raised and dissection continued to the base of exostosis, which was exposed and removed with a surrounding sleeve of periosteum. Tumor was then detached from soft tissues and removed in its entirety. The apophysis was approximated and repaired with number 1-vicryl.

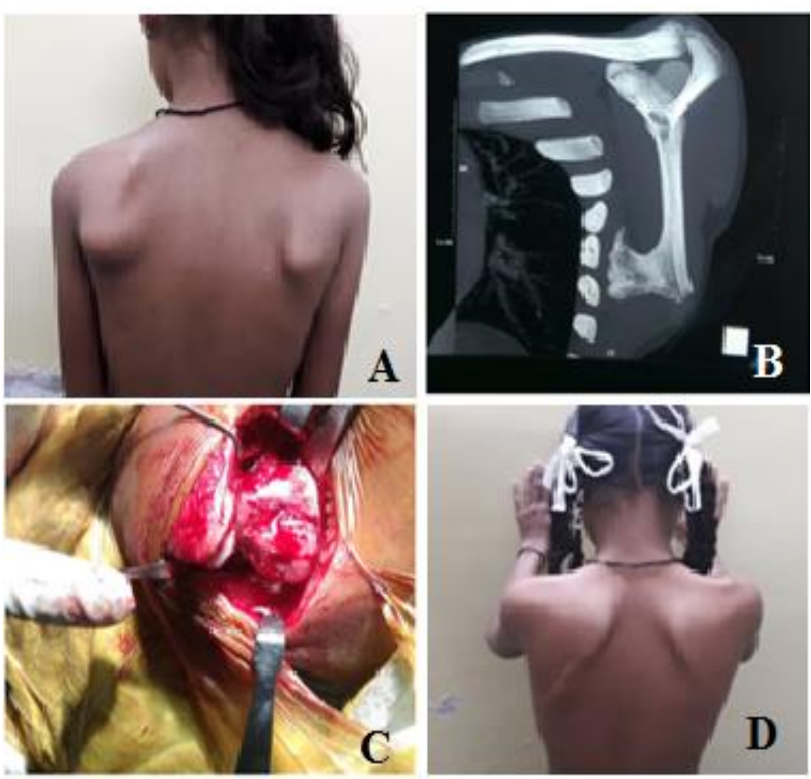

Figure 1: (A) pre-operative- pseudo-winging of left scapula (B) sagittal section through the left scapula showing the pedunculated bony mass at inefrior angle pressing against the rib cage $(C)$ intra-operative picture of the osteochondroma lesion arising from the ventral aspect of the inferior angle of left scapula (D) a 2 year follow up showed no evidence of recurrence \& disappearance of pseudo-winging.

The tumour had a characteristic mushroom shape with a surface covering of cartilage and bony peduncle which was continuous with the body of scapula. On macroscopy, the lesion measured $4 \times 3.5 \mathrm{~cm}$. Diagnosis was confirmed with histopathological examination. Post operatively the pseudo winging disappeared. Patient was started on shoulder mobilization from day one. Clinical results were evaluated with simple shoulder test at six months and two years after surgery. ${ }^{16}$ As per the simple shoulder test, she was able to use both shoulders equally and there was no compromise in her activities of daily living. Radiographs and CT scan at the end of 2 years revealed no evidence of recurrence.

\section{Case 2}

An 11-year-old boy presented with history of having noted a swelling on the left upper back since 5 months which had been progressively increasing in size (Figure 2). The swelling was painless however causes difficulty in lying supine. The parents were also concerned about the cosmetic blemish the swelling was causing. On examination a well-defined, smooth, bony hard swelling was palpable at the inferior angle of left scapula on the dorsal aspect. A scapular Y view radiography demarcated a well-defined, pedunculated bony outgrowth from inferior angle of left scapular dorsal surface suggestive of osteochondroma. CT scan further delineated the lesion. An MRI evaluation was done in view of the recent increase in size of the lesion. The thickness of cartilage cap was measured to be $2.54 \mathrm{~mm}$. He underwent excision and biopsy of the lesion through a trapezius sparing approach. The lesion measured $2.5 \times 1.5 \times 1.5 \mathrm{~cm}$. Histopathology confirmed the diagnosis of osteochondroma. Post operatively shoulder movements were commenced from day one as per pain tolerance.
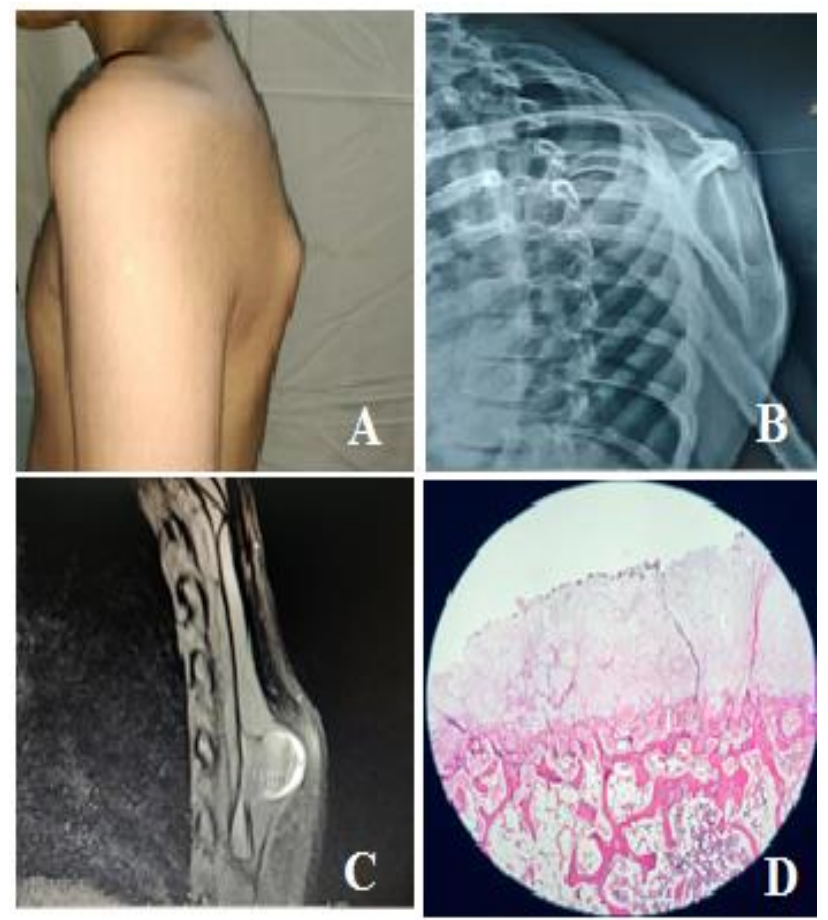

Figure 2: (A) a swelling over inferior angle of left scapula (B) scapular Y-view showing the dorsal osteochondroma lesion (C) MRI showed the cartilaginous cap which had a thickness of $2.54 \mathrm{~mm}$ (D) microscopy of the biopsied specimen showing cartilaginous cap with underlying bony trabeculae and hematopoietic islands $\mathrm{H} \& \mathrm{E}$, 40X. 


\section{Case 3}

A 15-year-old boy presented with a swelling over the back of his right shoulder for 3 years which was causing him difficulty in lying supine (Figure 3). On examination the swelling was found to be smooth, well defined, bony hard, non-tender and fixed to the spine of right scapula. It measured $3 \times 3 \mathrm{~cm}$. The shoulder range of motion was full and painless. No neurovascular deficits were noted. A scapular Y view radiograph \& CT Scan showed a sessile bony exostosis over the spine of scapula. An MRI showed the cartilage cap which measured $8 \mathrm{~mm}$ in thickness. He underwent an excision of the lesion along with a peripheral rim of periosteum. The excised tumour measured $3 \times 2.5 \times 1.3 \mathrm{~cm}$ and the histopathology confirmed the diagnosis of osteochondroma. Post operatively patient was started on early mobilisation of shoulder. The shoulder functional assessment with simple shoulder test found no restriction of activities. A 7 year follow up showed no evidence of recurrence of the tumour.
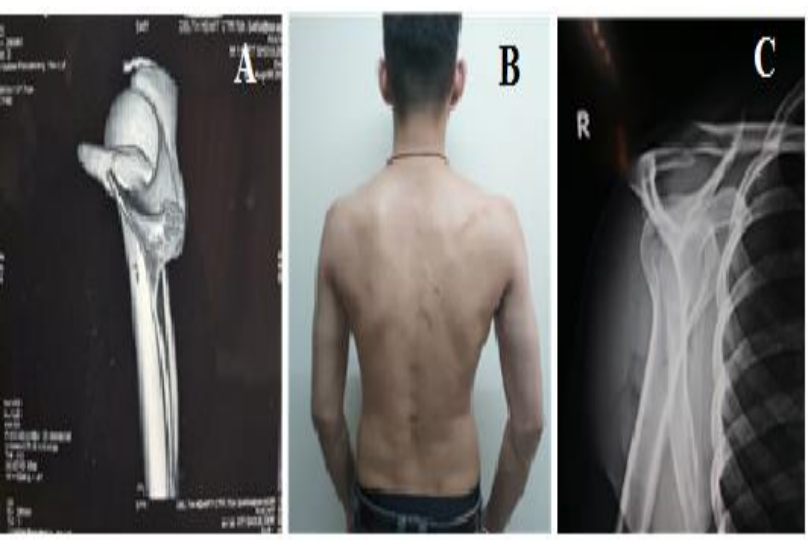

Figure 3: (A) Dimensional CT scan image showing the dorsal surface osteochondroma arising from spine of scapula (B) 7 years post excision patient had no clinical evidence of recurrence $(C)$ at 7 year follow up there was no radiological evidence of recurrence.

\section{DISCUSSION}

Osteochondroma typically presents in the metaphysis of the long bones and vast majority of them are asymptomatic and hence diagnosed incidentally. Flat bones including the scapula is a rare site for the occurrence of osteochondroma.
Scapular osteochondroma account for only $4 \%$ of osteochondromas however it's the commonest benign tumour occurring on scapula. ${ }^{17,18}$ After a detailed review of literature we observed that osteochondroma is more common on the ventral surface than dorsal. The ventral scapular osteochondromas tend to present with scapular pseudo-winging, snapping or crepitus, pain and bursal inflammation. Dorsal scapular osteochondromas are rarer and swelling and inability to lie supine are the chief presenting complaints. Also lesions commonly occur below the equator, closer to the inferior angle of scapula, and these are generally larger in size compared to superior lesions due to the extra space available for enlargement. ${ }^{4,10}$

The largest case series on scapular osteochondromas has been published by Frost et al which featured 8 cases. ${ }^{19}$ $62.5 \%$ of those originated from the ventral surface. All were treated with excision biopsy and at a mean follow up period of 4.17 years only one (12\%) recurrence was noted. Danielson \& el Haddad published a case series of 3 scapular osteochondromas, all were ventral in location and presented with pseudo-winging. ${ }^{14}$ Winged scapula or scapula alata is by definition a prominence of the medial border of the scapula. Winging is either dynamic or static. Dynamic winging is due to neurovascular disorders. Static or pseudo-winging is very rare and can be caused by any bony mass or abnormal curvature of the scapula on ventral surface pressing against the rib cage. Pseudo-winging of the scapula due to ventral osteochondromas has also been reported by Parsons ( 3 cases), Rinaldi ( 5 cases) and single case reports by many as given in table $1 . .^{20,21}$

Under normal circumstances the scapula glides over the rib cage cushioned by serratus anterior and subscapularis muscles. The superior and inferior angles and medial border are poorly cushioned and any bony irregularity, curvature or exostosis at these sites can lead to a grating sensation known as the snapping scapula syndrome. Carlson et al in his study evaluated 89 cases of snapping scapula syndrome, of which, only $3(3.4 \%)$ were due to osteochondroma of the scapula. ${ }^{22}$ Parsons reported 5 cases of snapping scapula due to subscapular osteochondromas. ${ }^{20}$ Case reports of snapping scapula secondary to ventral scapular osteochondromas has been reported by different authors. ${ }^{9-13}$ Our patient with subscapular osteochondroma had both pseudo-winging and snapping scapula at presentation.

Table 1: Ventral scapular Osteochondroma. ${ }^{4-14}$

\begin{tabular}{|c|c|c|c|c|c|}
\hline Case report & $\begin{array}{l}\text { Age of } \\
\text { presentation }\end{array}$ & Gender & Signs \& symptoms & Location & Size \\
\hline \multirow{3}{*}{ Danielsson et al ${ }^{14}$} & 11 years & Female & -Winging & Not mentioned & Not mentioned \\
\hline & 12 years & Male & -Winging & Inferior angle & Not mentioned \\
\hline & 6 years & Female & -Winging & Not mentioned & Not mentioned \\
\hline Alatassi et al $^{4}$ & 30 years & Male & -Pain, Winging & Inferior angle & $5 \times 5 \times 2 \mathrm{~cm}$ \\
\hline Sivananda et al $^{5}$ & 31 years & Female & -Pain, Bursitis & Supero-medial angle & $2 \times 1 \times 1$ inch \\
\hline Chun et al $^{6}$ & 14 years & Male & -Pain & Inferior ventral surface & $6 \times 6 \times 4 \mathrm{~cm}$ \\
\hline
\end{tabular}




\begin{tabular}{|c|c|c|c|c|c|}
\hline Case report & $\begin{array}{l}\text { Age of } \\
\text { presentation }\end{array}$ & Gender & Signs \& symptoms & Location & Size \\
\hline Mohsen et $\mathrm{al}^{7}$ & 19 years & Male & $\begin{array}{l}\text {-Pain, bursitis } \\
\text {-Winging }\end{array}$ & Medial border & $6 \times 5 \times 2.5 \mathrm{~cm}$ \\
\hline Aalderink et $\mathbf{a l}^{8}$ & Mid 20s & Female & $\begin{array}{l}\text {-Pain, Radicular pain } \\
\text {-Bursitis, Winging }\end{array}$ & Inferior angle & $3 \times 2.5 \mathrm{~cm}$ \\
\hline Kwon et al ${ }^{9}$ & 56 years & Female & - Pain, Snapping & Supero-medial angle & $7 \times 2.5 \mathrm{~cm}$ \\
\hline Nascimento et al ${ }^{10}$ & 21 years & Female & -Snapping, Pain & Superomedial angle & Not measured \\
\hline Tittal et al $^{11}$ & 23 years & Male & -Winging, Snapping & Superomedial angle & $3 \times 2 \times 1 \mathrm{~cm}$ \\
\hline Tungdim et al ${ }^{12}$ & 4 years & Male & $\begin{array}{l}\text { - Winging, Pain } \\
\text {-snapping }\end{array}$ & Inferior angle & $4 \times 3 \times 2.5 \mathrm{~cm}$ \\
\hline Tomo et al $^{13}$ & 23 years & Female & $\begin{array}{l}\text {-Pain, Winging } \\
\text {-Snapping }\end{array}$ & Supero-medial angle & $5 \times 5 \times 5 \mathrm{~cm}$ \\
\hline Vaishya et al ${ }^{23}$ & 18 years & Male & -Winging & Medial border & $\begin{array}{l}5.2 \times 2.9 \times 3.2 \\
\mathrm{~cm}\end{array}$ \\
\hline
\end{tabular}

Table 2: Studies reporting dorsal osteochondroma of scapula. ${ }^{15,24}$

\begin{tabular}{|c|c|c|c|c|c|}
\hline Case Report & $\begin{array}{l}\text { Age of } \\
\text { presentation(years) }\end{array}$ & Gender & Signs \& symptoms & Location & Size \\
\hline \multirow[t]{2}{*}{ Nekkanti et al ${ }^{24}$} & 然 & Male & $\begin{array}{l}\text {-Swelling } \\
\text {-Difficulty in lying } \\
\text { supine }\end{array}$ & Medial border & $5 \times 4 \times 1 \mathrm{~cm}$ \\
\hline & 5 & Male & -Swelling & Medial border & $1.5 \times 1 \mathrm{~cm}$ \\
\hline Mahajan et al ${ }^{15}$ & & Female & -Swelling & Lateral border & $8 \times 6 \times 3 \mathrm{~cm}$ \\
\hline
\end{tabular}

\section{Dorsal scapular Osteochondroma}

Dorsal surface osteochondromas of scapula are rarer compared to ventral. Only few case reports were identifiedas mentioned in Table 2. Frost et al reported 2 cases $(25 \%)$ of dorsal scapular osteochondromas in their case series. ${ }^{19}$ Nekkanti et al also reported 2 cases. ${ }^{24}$ Most of the patients presenting with osteochondroma on the dorsal aspect of scapula have been reported to be of the sessile variant. Dorsal osteochondromas usually present with swelling and difficulty in lying supine. We have encountered 2 patients with dorsal surface tumour, one sessile and one pedunculated variant. Both had complaints of difficulty in lying supine and they were more concerned with the cosmetic blemish caused by the tumour.

Osteochondromas of scapula are treated with excisionbiopsy and both arthroscopic and open approaches are described. Symptomatic cases should be excised at the earliest to decrease the risk of malignant transformation. Scapulothoracic arthroscopy first described by Ruland et al in 1995 have been used for excision of ventral scapular osteochondroma. ${ }^{25}$ This approach is minimally invasive, preserves muscle attachments, and thereby limits the need for immobilization in the postoperative period. ${ }^{8,10}$ Due to paucity of resources and lack of experience in scapulathoracic joint arthroscopy, open method is routinely used.

Open approaches include a medial para-scapular incision with trapezius \& or rhomboid major splitting. Historically extra-periosteal excision of osteochondroma has been the norm however recently sub-periosteal approach after splitting the medial scapular apophysis has been reported. ${ }^{26}$

We used the subperiosteal approach described by Brown \& Buckingham to excise the ventral scapular osteochondromas. ${ }^{26}$ This approach has the advantage of minimal muscle dissection and early rehabilitation. Stevens et al proposed the trapezius sparing approach which avoids the trapezius and rhomboid major splitting required in Medial para-scapular approach. ${ }^{26,27}$ We used this approach for the dorsal scapular osteochondroma. This too has the advantage of minimal muscle dissection \& early rehabilitation.

\section{CONCLUSION}

Osteochondroma of scapula may have unusual manifestation according to their location. One should be aware of these possibilities while dealing with a pathology in scapular region. Surgical resection of tumor is the treatment of choice. An appropriate surgical approach should be chosen depending on the location of tumor. We propose the use of trapezius sparing approach and splitting the scapular apophysis for subscapular osteochondroma in children as it produces less soft tissue damage, is easy to repair and allows early rehabilitation.

Funding: No funding sources

Conflict of interest: None declared

Ethical approval: Not required 


\section{REFERENCES}

1. Fletcher CD, Unni KK, Mertens F, editors. Pathology and Genetics of Tumours of Soft Tissue and Bone. 4th ed. Lyon, France: IARC Press; 2002.

2. Pongkripetch M, Sirikulchayanonta V. Analysis of bone tumors in Ramathibodi Hospital, Thailand during 1977-1986: Study of 652 cases. J Med Assoc Thail. 1989;72(11):621-8.

3. Barbosa CS, Araújo AB, Miranda D. Incidence of primary benign and malignant neoplasms and bone pseudotumoral lesions. An epidemiologic analysis of 585 cases diagnosed at the Faculdade de Medicina of the Universidade Federal de Minas Gerais. AMB Rev Assoc Med Bras. 1991;37(4):187-92.

4. Alatassi R, Koaban S, Almugebel I, Alshehri A. Scapular osteochondroma with winging: A case report. Int J Surg Case Rep. 2018;45:138-42.

5. Sivananda P, Rao BK, Kumar PV, Ram GS. Osteochondroma of the ventral scapula causing scapular static winging and secondary rib erosion. J Clin Diagn Res. 2014;8(5):LD03-5.

6. Chun DI, Cho JH, Choi IH, Yi Y, Kim JY, Kim JH, et al. Osteochondroma of ventral scapula associated with chest pain due to rib cage compression: A case report. Medicine. 2018;97(17):e0510.

7. Mohsen MS, Moosa NK, Kumar P. Osteochondroma of the scapula associated with winging and large bursa formation. Med Princ Pract Int J Kuwait Univ Health Sci Cent. 2006;15(5):387-90.

8. Aalderink K, Wolf B. Scapular osteochondroma treated with arthroscopic excision using prone positioning. Am J Orthop Belle Mead NJ. 2010;39(2):E11-4.

9. Kwon OS, Kelly JIV. Delayed presentation of osteochondroma on the ventral surface of the scapula. Int J Shoulder Surg. 2012;6(2):61-3.

10. 1Nascimento AT do, Claudio GK. Snapping scapula. Arthroscopic resection of osteochondroma of the subscapularis superomedial angle. Case report and literature review. Rev Bras Ortop. 2017;52(2):220-3.

11. Tittal P, Pawar I, Kapoor SK. Pseudo-winging of scapula due to benign lesions of ventral surface of scapula - Two unusual causes. J Clin Orthop Trauma. 2015;6(1):30-5.

12. Tungdim PH, Singh II, Mukherjee S, Pertin T. Excision of Solitary Osteochondroma on the Ventral Aspect of Left Scapula Presenting as Pseudowinging in a 4-year-old Boy: A Rare Case Report. J Orthop Case Rep. 2017;7(1):36-40.

13. Tomo H, Ito Y, Aono M, Takaoka K. Chest wall deformity associated with osteochondroma of the scapula: a case report and review of the literature. J Shoulder Elbow Surg. 2005;14(1):103-6.
14. Danielsson LG, el-Haddad I. Winged scapula due to osteochondroma. Report of 3 children. Acta Orthop Scand. 1989;60(6):728-9.

15. Mahajan S, Mahajan N, Singh P, Bashir A, Sharma Romesh C. Scapula a rare localization of osteochondroma: a case report. Internet J Orthop Surg. 2008;14(1):13.

16. Godfrey J, Hamman R, Lowenstein S, Briggs K, Kocher M. Reliability, validity, and responsiveness of the simple shoulder test: psychometric properties by age and injury type. J Shoulder Elbow Surg. 2007;16(3):260-7.

17. Essadki B, Moujtahid M, Lamine A, Fikry T, Essadki O, Zryouil B. Solitary osteochondroma of the limbs. Clinical review of 76 cases and pathogenic hypothesis. Acta Orthop Belg. 2000;66(2):146-53.

18. Samilson RL, Morris JM, Thompson RW. Tumors of the scapula. A review of the literature and an analysis of 31 cases. Clin Orthop. 1968;58:105-15.

19. Frost NL, Parada SA, Manoso MW, Arrington E, Benfanti P. Scapular osteochondromas treated with surgical excision. Orthopedics. 2010;33(11):804.

20. Parsons TA. The snapping scapula and subscapular exostoses. J Bone Joint Surg Br. 1973;55-B(2):3459.

21. Rinaldi E. Acquired winged scapula due to solitary bursal exostosis of the scapula. Arch Putti Chir Organi Mov. 1966;21:127-33.

22. Carlson HL, Haig AJ, Stewart DC. Snapping scapula syndrome: three case reports and an analysis of the literature. Arch Phys Med Rehabil. 1997;78(5):50611.

23. Vaishya R, Dhakal S, Vaish A. A solitary osteochondroma of the scapula. Case Reports. 2014 Feb 21;2014:bcr2013202273.

24. Nekkanti S, Moogali A, Meka A, Nair M. An Unusual Presentation of Osteochondroma on the Dorsal Surface of the Scapula: A Review of Two Patients. J Orthop Case Rep. 2018;8(3):38-41.

25. Ruland LJ, Ruland CM, Matthews LS. Scapulothoracic anatomy for the arthroscopist. Arthrosc J Arthrosc Relat Surg Off Publ Arthrosc Assoc N Am Int Arthrosc Assoc. 1995;11(1):52-6.

26. Brown C, Buckingham R. A new surgical approach to remove subscapular exostoses in children. Ann R Coll Surg Engl. 2011;93(3):258-9.

27. Stevens J, Stirling P, Patton JT. Trapezius-sparing Approach to Osteochondromas on the Ventral Surface of the Scapula. Tech Shoulder Elb Surg. 2018;19(3):124.

Cite this article as: Varughese AA, Pandey RA, Paul R, John B. Contrasting presentation of solitary scapular osteochondroma: a case series and review of literature. Int J Res Orthop 2021;7:148-52. 